\title{
Underachievement in Gifted Students: A Case Study of Three College Physics Students in Taiwan
}

\author{
Kuei-Fang Tsai ${ }^{1, *}$, Guopeng $\mathrm{Fu}^{2}$ \\ ${ }^{1}$ Department of Special Education, National Pingtung University, Taiwan \\ ${ }^{2}$ Faculty of Land and Food Systems, University of British Columbia, Canada
}

Copyright $\mathrm{O} 2016$ by authors, all rights reserved. Authors agree that this article remains permanently open access under the terms of the Creative Commons Attribution License 4.0 International License

\begin{abstract}
This case study provides an explanatory account on the underachievement of three gifted students studying physics in a Taiwanese university. The students' physics underachievement was diagnosed by Sato's student-problem analysis chart. These students were invited to complete a questionnaire and a follow-up interview in order to (1) understand the association between their academic performance, self-concepts, and support systems, and (2) elicit the pattern of their learning behaviors. Students reported that their self-worthiness was not undermined by their underachievement and they still believed in their own potentials. The study indicated that these students started to encounter academic problems during their senior high school years. The following learning habits resulted in their underachievement: (1) a lack of motivation and not applying self-actualization on subject matters, (2) focusing on memorizing and mastering skills and exercising counterproductive learning strategies, (3) a lack of genuine interest in the subject. This study also found that although these students had clear career goals and generally positive conceptualization of self, their professional development suffered from a lack of execution.
\end{abstract}

Keywords Underachievement, Giftedness, Learning Habits

\section{Introduction}

While gifted students tend to be perceived as having a better opportunity to succeed, the underachievement in gifted students has been discussed for a long time. There is no universal definition of a gifted underachiever [1]. Among numerous definitions of underachievers, Reis and McCoach [2] probably provide a most comprehensive one: "underachievers are students who exhibit a severe discrepancy between expected achievement (as measured by standardized tests, assessments, etc.) and actual achievement (as measured by grades and teacher evaluations)" (p.157). The patterns of underachievement must be in a long term, and not caused exclusively by the presence of a learning disability [1][3][4].

As early as in 1955, Gowan [5] pointed out the importance of studying underachievement of gifted students. He suggested that the underachievement of gifted children is the largest waste in a society [6]. Seeley [7] estimated that in the United States, $15 \%$ to $40 \%$ of gifted students may face the crises of underachievement or low achievement. Lupart and Pyryt [8] predicted that at least $21 \%$ of the gifted students in elementary school and junior high school in Canada experienced underachievement. U.S. Office of Education data suggested that as many as $50 \%$ of students in the top $25 \%$ high schools did not graduate from college [9]. The Commonwealth Magazine in Taiwan reported a case that a gifted physics student who was recommended for admission to National Taiwan University suffered from failures in college learning [10]. The underachievement of gifted students is a global issue and may occur to students at any stage of learning.

The characteristic behaviors of underachieving gifted students have been studied extensively since the 1950s. Generally speaking, researchers concentrated on three types of variables associated with underachievers among the gifted: home and parental variables, personality characteristics, and school related factors [11]. In her book Gifted grownups: The mixed blessings of extraordinary potential, Streznewski [12] suggested that gifted grownups usually face the issue of adapting to school, family, working environment, marriage, and life, as well as enabling people around them to accept them. Such a phenomenon shows that there is indeed a gap between the potentials of gifted students and their actual achievement. Many variables may affect them and impede them from exhibiting their talent and passion. Every gifted student has to face different challenges at various stages of life as well.

Siegle and McCoach [13] reported several causes of underachievement, including initiating situation, excessive power, inconsistence and opposition, and value conflicts. McCoach \& Siegle [14] used School Attitude Assessment 
Survey-Revised (SAAS-R) as the research tool to investigate gifted students with high and low achievement, and found that they both exhibited high academic self-perception. However, there was a significant difference in attitude toward school, attitude toward teachers and classes, motivation and self-regulation, and goal valuation. Among them, there is an $80 \%$ probability that motivation and self-regulation and goal valuation can be used to distinguish high achievers from low ones. McCoach \& Siegle [15] suggested that many factors may lead to the formation of underachievement of gifted students. If teachers can respond to the individual conditions of gifted students to trigger their learning motivation and self-regulation, their learning effectiveness may be improved.

Whitmore [16] found that some gifted students suffered from underachievement after going to senior high school because of the high pressure of academic performance and peer competition. In the discipline of physics, Du [17] suggested that the depth and width of knowledge, learning strategies or mathematical application of physics courses in senior high school are significantly different from junior high school physics courses. It is common that gifted students' underachievement occurs in senior high school and college. Baslanti and McCoach [1] claimed that few studies focus on underachieved gifted students in post-secondary level and there are few comparisons of achievers and underachievers in the literature, especially at the college level [18]. Hung [19] investigated the factors affecting the learning of college students in Taiwan and found that the effect of personal factors (stress from examination, learning interest, examination score, self-expectation, concentration, time management, learning motivation, etc.) is more significant than that of school and family factors. Wang, Peng, Chang, and Tseng [20] also suggested that underachieving gifted students may be characterized by the lack of learning motivation, lack of work commitment, bad habits, value conflict or low self-concept. It is advised to find out the cause-and-effect relationship or interactive model first and then prioritize the factors to establish the counseling goal.
What are the learning behaviors of underachieving gifted students at college? How do science majored students manage their own academic performance in college learning environment? How do their poor academic performances impact their self-concept? What do they think about their school, family, and peers? This study investigated the learning performance of underachieving gifted students. First, the research team recruited junior students who took the course of "modern physics" as potential participants for the in-depth interviews. Three underachieving gifted students participated in an analysis of the learning process of "one-dimensional infinite square well system" concept. Second, this study employed the "questionnaire on self-concept and external support system for underachieving gifted student" to understand underachieving students' self-concept and external support system. Third, our research team conducted in-depth interviews to understand underachieving students' thoughts and reflections on their own learning performance.

\section{Methods}

This case study employed document analysis and in-depth interviews as the principal data collection approaches. The researchers obtained information from three junior students in the Department of Physics who were identified as gifted students and experienced gifted student trainings in secondary schools but failed to perform well in their university physics courses. The study was conducted under university's ethics approval and students' consent was obtained. Research participants, research tools, and data analysis are described below.

\subsection{Research Participants}

This study selected three junior gifted students (including a senior student taking the makeup course) taking the course of modern physics at a university where author one served as instructor in 2010 academic year. The participants were denoted $\mathrm{A}, \mathrm{B}$, and $\mathrm{C}$, respectively. The basic information of participants is as follows:

Table 1. Basic Information of Research Participants

\begin{tabular}{|c|c|c|c|c|c|}
\hline Code & Gender & Grade & $\begin{array}{c}\text { Ranking of academic } \\
\text { performance of modern physic }\end{array}$ & $\begin{array}{c}\text { Educational } \\
\text { background of parents }\end{array}$ & $\begin{array}{c}\text { Average daily hours spent on study } \\
\text { review }\end{array}$ \\
\hline A & Male & Senior & $56 / 97$ & College, junior college & $1-2$ hours or less \\
\hline B & Male & Senior & $52 / 97$ & $\begin{array}{c}\text { Graduate school, junior } \\
\text { high school }\end{array}$ & $1-2$ hours or less \\
\hline C & Male & Fifth year & $46 / 97$ & $\begin{array}{c}\text { Senior high } \\
\text { school/vocational } \\
\text { senior high school }\end{array}$ & $1-2$ hours or less \\
\hline
\end{tabular}


The academic performance of three gifted students in class was generally poor, and participant $\mathrm{C}$ took the make-up course because he failed the course in previous year. Their academic performance in junior high school was great. However, their current performance was far from satisfactory. The descriptions of them are as follow:

Participant A was someone would ask the teacher loudly in class, "Will I get any points by studying the content?" and "Will I get any points by memorizing the content?" The Percentile Rank value of his Basic Competence Test for Junior High School Students was as high as 93/100. However, he almost failed every required course every year. When taking the make-up course for thermal statistical physics in the first semester of his senior year, he adopted the advice from the teacher and changed his learning strategies and achieved good academic standing. However, such good academic performance soon vanished in the second semester.

Participant B perceived himself as a hip-hop dancer insisting on being himself. He received a perfect score in English in the Basic Competence Test for Junior High School Students. However, his score in the Department Required Test was merely more than 10 points out of 100 . He spent most of his time on his favorite leisure activity hip hop. The updates on his Facebook were almost "dance showcase" and "I have an inspiration for rehearsal in the midnight and I cannot help dancing." He was frequently absent from the class. He aimed for graduate teacher education program but failed the admission examination. He was preparing for delayed graduation when the study was conducted.

Participant $\mathrm{C}$ is a passionate and persistent student association president. He took make-up courses of many required courses. As the student association president and department badminton team captain, he had a strong sense of responsibility for his duties. As long as the teacher requested him to do something, he would devote himself to the mission. He failed admission examination for graduate schools in the senior year. In his fifth year, he promised to himself that he would only study in top graduate schools. He is now enrolled in a top Graduate School of Physics in a top-ranked university in southern Taiwan.

\subsection{Data Collection Strategies}

1. Researchers - This study used researchers as a research tool. Therefore, the reliability and validity of this study were significantly correlated with the research methodology, skills, sensitivity, and honesty of the researchers [21]. The researchers authentically played their own role based on the research foundation of gifted education and science education.

2. Student-problem score table, S-P chart - The method provided item caution index and student caution index, and was able to concurrently analyze the test items and correct answer pattern of individual students to effectively diagnose the learning difficulties experienced by three students.

3. Questionnaire on Self-concept and External Support System for Underachieving Gifted Students - This questionnaire was revised from the "Questionnaire on the Self-concept and External Support System for Senior High School Students Failing to Overcome Underachievement" developed by Yang [22]. The content of the 48 items were completely identical, and only the descriptions for different learning stages of respondents were slightly modified. Items 1 to 22 investigated respondents' self-concept, including self-understanding (e.g. intelligence, self-expectation, self-confidence, sense of inferiority, self-evaluation, etc.) learning attitude (e.g. efforts made in schoolwork, learning attitude, fear for examination, etc.), and interpersonal relationship. Items 23 to 38 investigated respondents' "family support system," including parents' parenting attitude, communication method, family atmosphere, expectation attitude, and support for children' continuing study during their underachievement. Items 39 to 48 investigated "school support system," including the aspect of teachers (positive attitude, expectation, teaching method, and school examination method) and the aspect of peer group (including peer identification and support, study atmosphere in class, etc.)

4. Interview outlines for learning behavior performance of underachieving gifted students. The interview outlines included eight items, and were developed by the researchers. The last item was a multiple answer question where respondents were requested to verbally answer it. Before the formal interviews were conducted, a college student with similar background was invited to participate in the pre-test to determine whether the content of items was adequate. The interview process was audio recorded with participants' consent.

\subsection{Data Analysis}

1. To perform statistical analyses on student-problem score, S-P chart [23] - This study used S-P chart to perform analyses on the performance of three participants in this study, as well as that of other students concurrently taking the course of modern physics, in order to find out the correct answer rate, stability, and learning pattern of the three participants.

2. To transcribe the interview content into transcripts

3. Data coding and analysis - This study analyzed the transcripts of the interview data and identified the main themes and focuses of the three respondents based on their conversations and answers. Contextual information associated with the theme were also collected and analyzed. During the consecutive interview conversation process, the interview Q\&A sometimes included one to two sentences and sometimes included several sentences [24]. After examining the three transcripts, the researchers established categories based on the content and then gradually sifted the main themes in order to reach conclusions in the end [25]. 


\section{Results and Discussion}

\subsection{Problem solving performance and patterns of the three underachieving gifted students in learning of "one-dimensional infinite square well system"}

Table 2 shows the common two-way classification of students' correct answer rate and caution index [26]. The correct answer rate is divided into three levels based on the values. 75 and.50. Caution index is divided into two levels based on the value.50. The results of cross interaction are divided into 6 categories: good learning and high stability; stable learning and studying harder is required; lack of learning ability, insufficient learning and studying harder is required; mistakes are caused by carelessness; occasional carelessness, insufficient preparation, and studying harder is required; extremely unstable learning, arbitrary studying habit, and insufficient preparation for test content. The students taking the same course with three participants exhibited a total of six performances. The correct answer rate of participant $A$ in problems where memorization was required was better. Therefore, participant $\mathrm{A}$ belonged to category 2. Both participant $\mathrm{B}$ and participant $\mathrm{C}$ belonged to category 1 . The problem solving performance of 3 participants are shown in Table 3. The level of difficulty started to gradually increase from $\mathrm{C} 3$, where both memorization and understanding were required. Almost none of them provided the correct answers.

Table 2. Students' Performance Results Assessment Summary Table

\begin{tabular}{|c|c|c|c|c|c|}
\hline category & $\begin{array}{c}\text { Students' performance } \\
\text { (two-way classification cross interaction of student and } \\
\text { caution index) }\end{array}$ & $\begin{array}{c}\text { Scope of correct } \\
\text { answer rate }\end{array}$ & $\begin{array}{c}\text { Scope of student } \\
\text { caution index }\end{array}$ & $\begin{array}{c}\text { Number of } \\
\text { students }\end{array}$ & Percentage \\
\hline 1 & $\begin{array}{c}\text { Lack of learning ability, insufficient learning and studying } \\
\text { harder is required }\end{array}$ & $0-.50$ & $0-.50$ & 35 & 44.3 \\
\hline 2 & Stable learning and studying harder is required & $.50-.75$ & $0-.50$ & 31 & 39.2 \\
\hline 3 & Good learning and high stability & $.75-1.00$ & $0-.50$ & 3 & 3.8 \\
\hline 4 & $\begin{array}{c}\text { Extremely unstable learning, arbitrary studying habit, and } \\
\text { insufficient preparation for test content }\end{array}$ & $0-.50$ & $.50-1$ & 4 & 5.1 \\
\hline 5 & $\begin{array}{c}\text { Occasional carelessness, insufficient preparation, and studying } \\
\text { harder is required }\end{array}$ & $.50-.75$ & $.50-1$ & 3 & 3.8 \\
\hline 6 & Mistakes are caused by carelessness & $.75-1.00$ & $.50-1$ & 3 & 3.8 \\
\hline & Total & & $.50-1$ & 79 & 100 \\
\hline
\end{tabular}

Table 3. Problem-solving Performance of 3 Students

\begin{tabular}{|c|c|c|c|}
\hline Infinite Square Well Problem Solving Concept & Participant A & Participant B & Participant C \\
\hline A1 Writing down correctly a particle's Schrodinger eqs. in various areas & ○ & ○ & $\circ$ \\
\hline $\begin{array}{c}\text { B1 Correctly converting Schrodinger eqs. in various areas into second order differential } \\
\text { equations. }\end{array}$ & ○ & $\circ$ & $\times$ \\
\hline C1 Writing down correctly the boundary conditions. & $\circ$ & $\times$ & $\circ$ \\
\hline $\begin{array}{l}\text { C2 Using boundary conditions to calculate the energy levels and coefficients of } \\
\text { differential equations. }\end{array}$ & ○ & ○ & $\circ$ \\
\hline C3 Knowing the origin of boundary conditions. & $\times$ & $\times$ & $\times$ \\
\hline D1 Writing down correctly the normalization conditions. & $\times$ & $\times$ & $\circ$ \\
\hline $\begin{array}{l}\text { D2 Being able to calculate the probability distribution of various energy states and to } \\
\text { calculate the probability value of various energy states in various positions. }\end{array}$ & ○ & $x$ & $x$ \\
\hline $\begin{array}{l}\text { E1 Being able to use Heisenberg Uncertainty Principle to explain that when the number } \\
\text { of quantum is extremely large, the analysis result of quantum mechanics is consistent } \\
\text { with that of classical mechanics and the probability density is even. }\end{array}$ & $x$ & $\times$ & $\times$ \\
\hline $\begin{array}{l}\text { E2 Being able to use Heisenberg Uncertainty Principle to explain that when the system } \\
\text { size is extremely large, energy levels are continuous and the probability density is even. }\end{array}$ & $x$ & $x$ & $\times$ \\
\hline Correct answer rate & 0.56 & 0.33 & 0.44 \\
\hline Student caution index & 0.32 & 0.29 & 0.14 \\
\hline Students' performance pattern & 2 & 1 & 1 \\
\hline
\end{tabular}

o represents that the answer to the item is correct

$\times$ represents that the answer to the item is incorrect

1 Lack of learning ability, insufficient learning and studying harder is required

2 Stable learning and studying harder is required 


\subsection{The "Questionnaire on Self-concept and External Support System for Underachieving Gifted Students" results}

\subsubsection{Respondents' self-identification for the cause of underachievement and self-perception when facing underachievement}

Participant A had the highest level of agreement with Item 6 "I do not often have conflicts with other people," Item 16 "I do not feel that my self-esteem is hurt when facing underachievement," Item 18 "Other people will not despise me due to my underachievement," and Item 20 "I do not feel that I am worthless due to my underachievement."

Participant B had the highest level of agreement with Item 1 "I think that my intelligence is not inferior to that of my classmates," Item 3 "I think that my creativity performance is better than that of my classmates," Item 4 "I think that I have a very high expectation towards myself," Item 11 "I will not experience a sense of inferiority when I discuss with my classmates about the schoolwork," Item 13 "I understand the real cause for my underachievement," Item 19 "I think that I have an active learning attitude," Item 20 "I do not feel that I am worthless due to my underachievement," Item 21 "I still believe that my potential is unlimited in terms of my current status," and Item 22 "I did not care about my ranking in class in the past."

Participant $\mathrm{C}$ had the highest level of agreement with only one item in the aspect of self-concept of the questionnaire: Item 13 "I understand the real cause for my underachievement."

To sum up, it seemed that the self-concept of three participants was not affected by their underachievement and did not become negative. Two participants strongly agreed with Item 20 "I do not feel that I am worthless due to my underachievement" (4 points; the highest score), and one participant somewhat agreed (3 points) with it. Moreover, the three participants strongly agreed or somewhat agreed with Item 21 "I still believe that my potential is unlimited in terms of my current status" ( 4 points, 3 point, and 3 points).

\subsubsection{Support from Family, Peer Group, and Teacher when Facing Underachievement}

Family Support System

Participant A had the highest level of disagreement with Item 23 "My parents will not blame me for my underachievement" and Item 33 "My parents will not compare the performance of my siblings, relatives, or classmates with mine to form pressure for me," followed by Item 24 "My parents will not worry about my future owing to my underachievement," Item 25 "My academic performance will not affect my communication with my parents," Item 26 "The harmonious family atmosphere will not be affected by my academic performance," and Item 31 "My parents hold an adequate expectation towards my academic performance." Participant A indicated that his parents hoped that he could graduate from the school smoothly. He even came to the teacher's office to claim that his parents could not afford his study in the fifth year when he was certain that he failed the required courses, suggesting that he did feel the pressure from family expectation.

Participant B had the highest level of disagreement with only one item: Item 30 "My parents' expectation towards my academic performance is consistent." There was no significant difference in the rest of the items.

The items with which participant $C$ had the highest level of agreement were similar to those of participant $\mathrm{A}$, such as Item 24 "My parents will not worry about my future owing to my underachievement" and Item 26 "The harmonious family atmosphere will not be affected by my academic performance."

\section{School support system}

The 3 participants all indicated that "I spend too much time playing around with my classmates or on extracurricular activities" (participant B's response was 4; participant A and C's response was 3). They all disagreed with Item 46 "Most of my friends are those who attach high importance to academic performance." The fact showed that their friends were not those who enjoy studying in class.

In terms of school teachers and learning environment, the participants all agreed that they perceived the support from the school and teachers. Participant A used to pay attention to his academic performance for a while owing to the instruction from the teacher. Consequently, his response for Item 43 "I will consult with teacher or classmate when encountering academic problems" was 4 points. Participant B' response was 4 as well. The score of Item 39 "School teacher usually encourages me" was high as well. It is interesting that all 3 participants responded that the place where they do their schoolwork most frequently was "school."

\subsection{Thoughts and Reflections of Underachieving Gifted Students on their Own Learning Performance}

\subsubsection{Causes for the Underachievement in Senior High School Learning}

\section{Participant A}

Lack of interest in academic study

As a matter of fact, my academic performance started to fall behind since the second semester of sophomore year. To be more specific, my ranking started to fall down since the first examination in freshman year and was never improved ...because I did not think about studying in college after going to senior high school. I intended to become a chef...In fact, my underachievement is also associated with my physical status. My memory was poor at that time...I just memorized formulas without understanding them. I did not understand what exactly the teacher instructed in class. 


\section{Participant B}

Having a dislike for a certain teacher or certain learning methods

I did not like the chemistry teacher in class at that time...I think that teachers do have a significant impact on me. In fact, many students are also affected by teachers...I hated learning anything by memorizing it. I think that the best way to learn is to understand it. For example, it is necessary to explain the theory of a certain reaction in chemistry for me.

I did not dislike the English teacher. I was too lazy to memorize vocabularies. At that time, I thought that it was not necessary to learn English well as long as I can communicate with people in English.

Participant C

My EQ was very poor since my childhood. I cannot manage my emotion well. I tend to get angry or burst into tears in peer groups. I tend to be isolated from classmates...I was assigned to the class of poorer level in senior high school, so my learning habit naturally worsened. However, somehow my desire to go to school become stronger ...even though I do not care about whether I am in first place or not.

\subsubsection{Causes for the Continuous Underachievement of College Learning}

Lack of learning motivation and self-actualization for academic performance:

\section{Participant A}

I almost did not study at all in sophomore and junior years...I lacked learning motivation and did not find it important to be in first place. I thought that poor academic performance does not matter at all. I just tried to pass the required courses.

\section{Participant B}

In general, I would concentrate on the content in the first few classes, and then even never attended the class.

I would be interested in the course that I did not take. However, I would not like to learn anything in the course I took. I hate to learn due to being criticized or stressed. I dance happily because no one forces me to dance.

\section{Participant C}

I just played around in the freshman and sophomore years. I started to study since the junior and senior years...As a matter of fact, I did study many subjects until in the junior year. Compared with other gifted students in the past, I am just a mediocre student.

I thought that it was necessary to study hard in the freshman year. I kept taking notes in class and reviewing the notes before the examination. However, when I got the exam paper, I found that I could not answer any question. The reason was that the test questions were the practice questions in the textbook. I did not buy the textbook, and had no idea that the test questions would be the practice questions. I felt that I was pranked, and gave up studying. When there were more professional courses to be taken, it was difficult to get good grades in every subject. My started to uphold the attitude that studying in college is just to get every subject passed.

I was busy handling the matters concerning the student association in the sophomore and junior years. Half of my time was spent on student association.

\section{Sticking to the wrong learning strategies}

\section{Participant A}

Because I did not intend to win the first place, I simply hoped to have every subject passed.

It was more embarrassing that I found that I could understand the concepts of the course when reading the book or asking someone a question. During my practice, I found it easy to calculate answers. Besides, I could even explain the concepts to other classmates for one for two hours without feeling anything strange. After writing down the concepts twice, I could extend them to some questions. However, I could not smoothly apply the concepts to the problem-solving in the examinations.

I used the learning strategies as recommended by the teacher. However, I did not find it as smooth as that in study thermal statistical physics. Honestly speaking, I did not do anything else. I even thought it was acceptable to give up studying hard.

\section{Participant B}

I have the ability to study well. However, I do not have the motivation...I hate keeping studying hard. I found that I am really anticlimactic at times. I did not study well.

I think that my values are more important than academic learning.

\section{Participant C}

I did not find it hard to stay concentrated in class. However, I would not like to review the course content after class.

I could learn and understand something rapidly. However, I was unwilling to spend time on it.

It is hard to request me to get a high score unless I am willing to keep studying without taking a rest. I think that I just want to be happy.

I do not care about the academic performance of other classmates. The only difference between the first place and other places is just a little more scholarship. It really means nothing.

\section{Excuses and Concept of Cost-Efficiency}

\section{Participant A}

I originally intended to apply for a better school during the application for admission. However, after thinking about it, I found that it might be risky. However, I hate to take the examination. 
Compared with other classmates in gifted class in the past, my academic performance was poorer. I have never heard that any of them may have any difficulty in getting graduated.

Now, I think that the objective of learning is to get employed in the future. Because I have heard many people say that what they have learnt is not useful at all at work. To make money, many people will learn the investment skills about stocks, futures, etc. Some people will take the examination of certified public accountant or actuary, and others will take senior civil servant examination in order to become public officials. I have never heard anyone engaging in occupations concerning physics.

Participant B

I was not afraid of being flunked. I thought that I could always take the makeup course later. As a result, I almost cannot even get graduated now.

In junior high school, I was too young to develop a wide perspective. My teacher said that I have to study hard to have a more promising future. Therefore, I used to study hard in the past. However, I do not think that studying is the most important thing now.

I really do not like the education in Taiwan. Students will be criticized for doing things (e.g. studying physical education or music) other than studying academic disciplines. Only when you become a super star will you be praised as the honor of Taiwan. The academic world in Taiwan seems to reflect such a value.

\section{Participant C}

My parents never ask me to study hard for better academic performance. They always show respect to my choices.

Getting a high score does not represent that you completely understand a subject. In addition, being able to understand a subject does not represent that you have to get a high score.

The situation in my junior year repeated in the senior year. Although I did not suffer from the pressure from students association in the senior year, there was another pressure graduate school.

\section{Strong in Persistence for Career Planning, but Weak in Execution}

\section{Participant A}

I would like to start to use my time to buy some books and prepare for civil servant examination during my alternative service. I would not go to cram school because going to cram school requires specific period of time.

I would not prepare for graduate school admission examination. If I would like to go to graduate school in the future, I will plan for it.

\section{Participant B}

I would like to become a junior high school physics teacher. However, I failed the examination.
I am more negative recently, and tend to be absent from the class. It's hard for me to tell my family about the delayed graduation.

I think it is not important to study because experiences are more valuable. Experiences are more important than studying. I really think that academic performance does not mean anything since I have not decided my career planning.

I found it difficult for me to study hard now.

\section{Participant C}

I think that I am still the same person. I still will do the same thing without any change. I will neither buy textbooks nor care about the ranking...I just want to be happy.

\section{Conclusions and Recommendations}

The purpose of this study is to investigate the learning performance of underachieving gifted students in Department of Physics in college. This study analyzed the problem-solving process of 3 underachieving gifted participants during the learning of an important concept in Modern Physics course. This study also intends to understand the self-concept and external support system of underachieving gifted students through questionnaire. Moreover, this study used in-depth interviews to understand underachieving gifted students' thoughts and reflections on their own learning performance. The conclusions and suggestions are described as follows:

1. The results of the problem-solving performance and pattern for the learning of "one-dimension infinite square well" reflected their learning behavior and attitude. The correct answer rate decreased with the complexity of item concepts, suggesting that the participants did not completely understand the concepts and were dependent on memorization.

2. The responses to the questionnaire on "self-concept and external support system of underachieving gifted students" showed that, the participants did not develop negative self-concept. In addition, they did not suffer from too much family pressure owing to current academic performance. The reason might be that the participants did not reveal the information to other classmates that they used to be gifted students with excellent academic performance. There was no tokenization effect. It seemed that their personal traits did not include perfectionism and success oriented. Chang's follow-up study [27] on gifted students with excellent academic performance in senior high school mathematics and natural science found that, the gifted students who have higher self-expectation perceive more pressure from other people around them. The participants in this study did not experience learning pressure. Whether such a phenomenon is associated with the absence of high self-expectation is worth further investigation.

3. Participants started to accumulate the experiences of failure since senior high school. The atmosphere of peer competition was not significant and the reason might be the 
teacher or pedagogical approaches or the property of course. Such facts showed that as participants attached less importance to academic performance, their ranking worsened. However, they did not exhibit any aggressive behavior to change it. They simply relied on their good academic performance in one or two subjects to get enrolled in college. They chose department and school near their home in an attempt to escape from Department Required Test. They usually would not go to cram school or engage in other learning activities in leisure time.

4. The research results are similar to the studies mentioned above. It seems that factors affecting gifted students' behaviors and general college students are similar. The underachievement of gifted students in junior high schools probably follows their adult career performance or choice. It is important to provide early intervention and prevention strategies [20]. Family, school, peers, and teachers should cooperate with one another to help trigger students' motivation for creating success or develop their learning strategies and skills. It is important for educators to assist gifted students to find themselves and become a "spontaneous changer" to reverse underachievement.

\section{REFERENCES}

[1] U. Baslanti, \& D. B. McCoach. Factors related to the underachievement of university students in Turkey. Roeper Review, 28(4), 210-215.2006.

[2] S.M. Reis, \& D. B. McCoach. The underachievement of gifted students: What do we know and where do we go? Gifted Child Quarterly 44, no. 3, 152-170. 2000.

[3] J Ritchotte, L. Rubenstein, \& F. Murry. Reversing the underachievement of gifted middle school students. Gifted Child Today, 38(2), 103-113. 2015.

[4] R. A. Schultz. Illuminating realities: A phenomenological view from two underachieving gifted learners. Roeper Review, 24(4), 203-212. 2002

[5] J. C. Gowan. The underachieving gifted child: A problem for everyone. Exceptional Children, 21:247-249; 270-271. 1955.

[6] D. M. Tsai. Issues and evaluation of underachieved gifted students. Gifted Education Quarterly, 91, 1-7. 2001.

[7] K. R. Seeley. Gifted students at risk. In L. K. Silverman (Ed.), Counseling the gifted and talented, (pp.263-276). Denver: Love. 1993.

[8] J. L. Lupart, \& M.C. Pyryt. "Hidden gifted" students: underachiever prevalence and profile. Journal for the education of the gifted, 20(1), 36-53. 1996.

[9] U.S. Department of Education. National excellence: A case for developing America's talent. Washington, D.C.: Office of Educational Research and Improvement. 1993.

[10] S. K. Kao. No future for the gifted: Physics gifted students in trouble. Global Views Monthly, 200. 150-152. 2003.
[11] B. Clark. Growing up gifted (5 $5^{\text {th }}$ ed.). Upper Saddle River. NJ: Prentice Hall. 1997.

[12] M.K. Streznewski. Gifted Grownups: The Mixed Blessings of Extraordinary Potential. Wiley. 1999.

[13] D. Siegle, \& D. B. McCoach. Issues related to the underachievement of gifted students. In B. MacFarlane \& T. Stambaugh (Eds.) Leading change: The festschrift of Joyce VanTassel-Baska (pp. 195-206). Waco, TX: Prufrock Press. 2009

[14] D. B. McCoach, \& D. Siegle. Factors That Differentiate Underachieving Gifted Students From High-Achieving Gifted Students. Gifted Child Quarterly, 47(2), 144-154. 2003.

[15] D. B. McCoach, \& D. Siegle. Underachievers. In J.A.Plucker \& C.M. Callahan (Eds.) Critical issues and practices in gifted education: What the research says (pp.225-240). Waco, TX: Prufrock Press Inc. 2008.

[16] J. R. Whitmore. Giftedness, conflict, and underachievement. Boston: Allyn and Bacon. 1980.

[17] D. S. Du. Pedagogical recommendations on the new high school physics course outline. Physics Bimothly, 28(3), 527-535. 2006.

[18] J. S. Peterson. Successful adults who were once adolescent underachievers. Gifted Child Quarterly, 45, 236-249. 2001.

[19] B. L. Hung. Assessment of university student learning strategies. Measurement and guidance, 1992, Apr (111): 2246-2247. 1993.

[20] W. L. Wang, J. C. Peng, W. C. Chang, \& S. H. Tseng. A Case Study of Assisting a Secondary School Gifted Underachiever Through Bibliotherapy. Bulletin of Eastern-Taiwan Special Education, 8,169-190. 2006.

[21] M. Q. Patton. Qualitative Research \& Evaluation Methods: Integrating Theory and Practice. Sage Publish. 2014.

[22] G. N. Yang. A comparative study of senior high school students who overcome underachievement or not among their psychological characters, self-concepts, and external support systems. Unpublished Master thesis, Department of Special Education, National Kaohsiung Normal University, Kaohsiung, Taiwan. 2004.

[23] T. Sato. The S-P chart and the caution index. NCE Educational Information Bulletin, 80-1. 1980.

[24] W. M. Hsu. The Implementation of Mathematics Curriculum: A Case Study of Three Sixth-Grade Teachers. Bulletin of Educational Research, June, 57(2), 85-120. 2011.

[25] S. C. Huang. Why do they smoke: Qualitative analysis of university student sample. Chinese Journal of School Hearth. 33, 3-15. 1998 .

[26] M. N. Yu. Principles for the Development of Achievement Test. Taipei: Hsin Li Publishing. 1996.

[27] Y. R. Chang. A report on follow-up studies of mathematics and physics gifted high school student after graduation. Science Education Monthly, 230, 64 -70. 2000. 